\title{
A STUDY ON THE DESIGN OF THERMOSYPHON EVAPORATOR USED IN NUCLEAR WASTE VOLUME REDUCTION METHOD
}

\author{
M. Arul Jayan ${ }^{1, *}$, C. Marimuthu ${ }^{2}$, V. Thiyagarajan ${ }^{3}$ and S. Senthil Velavan ${ }^{4}$ \\ ${ }^{1}$ Department of Chemical Engineering, Sethu Institute of Technology, Pulloor, \\ Viruthunagar District, India \\ ${ }^{2}$ Chemical Engineering Department, Higher College of Technology, Muscut, Oman. \\ ${ }^{3}$ Department of Chemical Engineering, Sathyabama University, Chennai, India. \\ ${ }^{4}$ Department of Mechanical Engineering, Dr. Pauls Engineering College, \\ Pulichapallam, Tamilnadu, India \\ *E-mail: shajivenoth@gmail.com
}

\begin{abstract}
The volume of High-Level Liquid Nuclear Waste (HLLW), produced during the operation of reprocessing of nuclear waste is very high. These wastes may contain radioactive elements such as $\mathrm{Cs}, \mathrm{Sr}, \mathrm{U}, \mathrm{Pu}, \mathrm{Ru}, \mathrm{etc}, \mathrm{Along}$ with their isotopes and many other harmful elements. These HLLW from the plant were sent for permanent storage .The quantity of the waste is high if stored in the waste vault; it required larger tanks and constant surveillance. In this study Thermosyphon evaporator was designed to reduce the volume of the HLLW, and by introducing evaporation process before storing the nuclear waste the study highlights that the total volume is reduced half the original volume. This process of evaporation reduces the total volume to half of its original value with the limitation of its acidity not exceeding 6. Since it is the maximum limit at which the corrosion level is optimum of lesser than 15 mills per year and it exceeds drastically at higher acidity.
\end{abstract}

Key words: Nuclear waste, Volume reduction, Evaporation, Thermosyphon evaporator

(c) RASĀYAN. All rights reserved

\section{INTRODUCTION}

During the operation of the nuclear process they generate two types of wastes they are high-level waste and low-level wastes. High-level waste consists of spent fuel, fission products and transuranic materials generated during the fission reaction. Low-level wastes are filters, resins used for purification. ${ }^{1}$ Waste processing methods are employed for the recovery and handling of noble metals one such method which is suggested by many researchers is volume reduction. ${ }^{2}$ The various processes available for volume reduction are Evaporation method, Ion exchange Method Reaction with formaldehyde under the boiling condition, Reaction with formic acid, Action of sucrose with Nitric acid, Reaction of Ethanol and acid, Electrolytic method, Membrane separation method. Leaching studies on nuclear waste have been studied. ${ }^{3}$ Evaporation is a proven method for the treatment of liquid radioactive waste. This process also produces clean condensate and also considered as the best technique for waste which has high salt content. ${ }^{4}$ High level liquid wastes are first cycle raffinates it also includes fission products thus they should be stored in suitably designed tanks, but this method is safe under close surveillance. ${ }^{5}$ In this paper volume reduction of high-level nuclear waste was performed with the help of evaporation process performed in a Thermosyphon evaporator, the condensate, raffinates were analyzed for its acidity value. The equipment used for volume reduction was designed by using the design equations. ${ }^{6}$

\section{EXPERIMENTAL}

High-level radioactive liquid waste (raffinate) that has been generated from reprocessing plants is stored in raffinate feed storage tanks. This raffinate is concentrated by evaporation to reduce the required storage 
RASĀYAN J. Chem.

Vol. 11 | No. 1 |307 - 311 | January - March | 2018

volume. The thermosyphon evaporator is fed continuously by air lift pump at a designed flow rate $400 \mathrm{lph}$ from rafiinate feed storage tank. The flow rate is measured by rotameter and controlled by an automated operated valve. The liquid level in the evaporator is controlled by level indicating sensors which actuates feed control valve. The liquid waste is heated by steam to its boiling point by a steam tube bundle located within the evaporator. The steam supply is regulated by a flow control valve. The temperature in the evaporator is maintained about $378 \mathrm{~K}$. The vapor which is generated in the evaporator contains liquid droplets that are contaminated with radioactive cesium and other trace radio nuclides. The vapor is passed through a high-efficiency demister pad to remove all liquids and thus removes the radioactive contaminants. The demister pad is located at the top of the evaporator. Overhead vapor is condensed in a shell and tube heat exchanger called Downdraft condenser and then collected in a low-level waste storage tank at a flow rate of $150 \mathrm{lph}$. This low-level condensate waste is discharged to the environment when its activity is below the permissible level. Noncondensable gases coming off the overhead condenser are passed through high-efficiency particulate (HEPA) filter and monitored for radioactivity before being vented to atmosphere. Waste concentrate called as high-level liquid waste is removed and stored in the high level liquid waste storage tank.

Corrosion and erosion are generally more severe problems in evaporators than any other types of equipment because of the necessary concentration differences, the frequent presence of solids in suspension and the high velocities of vapor and liquid.

Foaming is often a major problem because of the presence of soaps and detergents in varying concentrations. Even with trace levels of foaming agents, serious foaming occurs under vigorous boiling conditions in an evaporator and this leads to an operating flow rate considerably below the designed throughput. Evaporators depend entirely upon good heat transfer for their operation and scaling results in overall resistances to heat transfer increasing with time. The design of evaporators was performed to analyze important parameters with the help of material balance and energy balance. When the energy balance is calculated the load from vapor is calculated from the following equations:

Load from vapor $\left(\mathrm{Q}_{\mathrm{v}}\right)=\dot{\mathrm{m}} \lambda_{e v}=\mathrm{q}_{\mathrm{v}} \times \rho \times \lambda_{\mathrm{ev}}$

Load from liquid $\left(\mathrm{Q}_{\mathrm{P}}\right)=q_{f} \times \rho \times\left(H_{v}-H_{L}\right)=\left(\mathrm{q}+q_{c}\right) \times \rho_{v} \times\left(H_{v}-H_{L}\right)$

From Coulson and Richardson Vol-6 many important parameters were identified and the relations expressed in the above-said book is used to calculate these parameters. Total heat load was found by summing up the load from vapor and load from the liquid.

Heat transfer area required $=\frac{\mathrm{Q}}{\mathrm{U} \times \Delta \mathrm{T}}$

Flow area available is calculated by $=\frac{\pi}{4} D_{i}^{2} \times$ no of tubes

The bundle diameter $D_{b}=D_{o}\left(N_{t} / K_{1}\right)^{1 / n_{1}}$

For triangular pitch $K_{1}=0.319 n_{1}=2.142, \quad \mathrm{~N}_{\mathrm{t}}$ is total number of tubes and $D_{b}=33.528 \mathrm{~mm}(32 / 0.319)^{1 / 2.142}$

Pressure drop inside the evaporator was calculated using the relation:

$\Delta P=8 j_{f}\left(\frac{L}{D_{i}}\right)\left(\frac{\rho u^{2}}{2}\right)$

Static pressure inside the tubes is calculated using:

$\Delta P_{s}=\frac{g L}{\left(v_{0}-v_{i}\right)} \times \ln \left(\frac{v_{0}}{v_{i}}\right)$ 
In forced-convective boiling, the effective heat-transfer coefficient $\mathrm{h}_{\mathrm{cb}}=h_{f c}^{\prime}+h_{n b}^{\prime}$, The convective boiling co-efficient is expressed by $h_{f c}^{\prime}=h_{f c} \times f_{c}$ and Nucleate boiling co-efficient $h_{n b}^{\prime}=h_{n b} \times f_{s} \quad$ Overall Heat transfer Co-Efficient was calculated from the relation:

$$
\frac{1}{U_{C}}=\frac{1}{h_{i}} \frac{D_{o}}{D_{i}}+\frac{X_{W}}{K_{m}} \frac{D_{o}}{D_{L}}+\frac{1}{h_{o}}
$$

Dirt co-efficient was calculated using:

$$
R_{d}=\frac{U_{C w}-U_{D}}{U_{C w} U_{D}}
$$

\section{Design of Thermosyphon Evaporator Assumption}

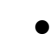

The influence of fission products on physical properties is neglected.

The properties of water are used for feed and concentrate.

\section{Vapor Chamber Design}

From IAEA Tech Rep Series 87 (1968), p-34, DF $=1.2 \times 10^{14} \mathrm{G}^{-3.7}$ ( for $\mathrm{G}=145$ and above )

For DF $=1000$, the $G=\left(\frac{1000}{1.2 \times 10^{14}}\right)^{\frac{1}{-3.7}}=987.13 \mathrm{~kg} / \mathrm{hr} \mathrm{m}^{2}$.

As the vapor mass flow rate is $149.69 \mathrm{~kg} / \mathrm{hr}$. the cross-sectional area of vapor chamber $\mathrm{A}_{\mathrm{v}}=0.53 \mathrm{~m}^{2}$ hence the diameter of vapor chamber $\approx 493 \mathrm{~mm}$.

As the vapor flux is high, the diameter of vapor chamber is increased to $700 \mathrm{~mm}$ to reduce the vapor flux below $400 \mathrm{~kg} / \mathrm{m}^{2} \mathrm{hr}$.

As per IAEA Tech Rep Series 87 (1968), p-33, experiments under normal boiling conditions (mass velocities below $400 \mathrm{~kg} / \mathrm{m}^{2} \mathrm{~h}$ ) show that the height of drops above the liquid level does not become extremely great due to vapour velocity and the conclusion is reached that if the height of vapour space is about 0.6 to $1.1 \mathrm{~m}$, it is improbable for the jetted drops to reach the vapour outlet directly. Hence vapor chamber height of $1.5 \mathrm{~m}$ is recommended for the evaporator. A Demister is provided inside the vapor chamber to enable mist elimination.

\section{Steam Inlet Nozzle Size}

Latent heat of steam

Specific volume of Steam

$$
\begin{aligned}
& =2185.5 \mathrm{~kJ} / \mathrm{kg} \\
& =0.749 \mathrm{~m}^{3} / \mathrm{kg} \\
& =\frac{\text { heat load }}{\text { latent heat }}=\frac{462257.25 \mathrm{~kJ} / \mathrm{hr}}{2185.5 \mathrm{~kJ} / \mathrm{kg}} \\
& =211.51 \mathrm{Kg} / \mathrm{hr} \\
& =0.749 \times 211.51=158.42 \mathrm{~m}^{3} / \mathrm{hr} .
\end{aligned}
$$

Steam required

Volume of steam required

Assuming a velocity of $15 \mathrm{~m} / \mathrm{s}, \mathrm{c} / \mathrm{s}$ area required $=0.003 \mathrm{~m}^{2}$.

Diameter $=0.062 \mathrm{~m}=62 \mathrm{~mm}$

Hence 50 NB Sch 40 SS pipe can be used

\section{Steam Condensate Drain Nozzle Size}

Specific volume of condensate

Condensate volume

$$
\begin{aligned}
& =1.0658 \times 10^{-3} \mathrm{~m}^{3} / \mathrm{kg} \\
& =1.0658 \times 10^{-3} \times 211.51 \mathrm{~kg} / \mathrm{hr} \\
& =0.2254 \mathrm{~m}^{3} / \mathrm{hr} .
\end{aligned}
$$

Assuming a velocity of $0.3 \mathrm{~m} / \mathrm{s}, \mathrm{c} / \mathrm{s}$ area required is $2.08 \times 10^{-4} \mathrm{~m}^{2}$

Diameter $=0.0162 \mathrm{~m}=16.2 \mathrm{~mm}$ 
RASĀYAN J. Chem.

Vol. 11 | No. 1 |307 - 311 | January - March | 2018

Hence 15 NB Sch 40 SS pipe can be used

\section{Feed and Outlet Nozzles}

Total liquid Feed is $($ Condensate + Concentrate $)=400 \mathrm{lph}$

Assumed Velocity is $0.3 \mathrm{~m} / \mathrm{s}$

Area of flow will be $3.7 \times 10^{-4} \mathrm{~m}^{2}$

Diameter is $21.4 \mathrm{~mm}$

Hence 20 NB Sch 40 SS pipe can be used

Table-1: Material balance for Thermosyphon evaporator

\begin{tabular}{l|c|c|c}
\hline Parameters & Feed & Concentrate & Distillate \\
\hline Flow Rate in $\mathrm{lph}$ & 400 & 250 & 150 \\
\hline Density in $\mathrm{kg} / \mathrm{m}^{3}$ & 1230 & 1315 & 1080 \\
\hline Normality N & 3.65 & 5.0 & 1.4 \\
\hline Weight percentage of $\mathrm{HNO}_{3}$ & 23 & 31.5 & 8.82 \\
\hline Weight percentage of $\mathrm{H}_{2} \mathrm{O}$ & 77 & 68.5 & 91.18 \\
\hline$\beta, \mathrm{g}$ activity $\mathrm{Ci} / \mathrm{l}$ & 70.04 & 709.81 & $700.4 \times 10^{-6}$ \\
\hline
\end{tabular}

Table-2: Energy Balance for thermosyphon evaporator

\begin{tabular}{c|c|c|c|c}
\hline Parameters & Flow Rate in lph & Temperature in K & Enthalpy in KJ/kg & Total Enthalpy in KJ/hr \\
\hline Feed in & 400 & 303 & 125.60 & 50240.0 \\
\hline Steam in & 170.3 & 400 & 2714.40 & 462262.32 \\
\hline Total & & & & 512502.32 \\
\hline Concentrate out & 250 & 378 & 439.96 & 109990.0 \\
\hline Vapor out & 150 & 378 & 2683.40 & 402510.0 \\
\hline Total & & & & 512500.0 \\
\hline
\end{tabular}

Table-3: Design Summary of Thermo Siphon Evaporator

\begin{tabular}{|c|c|}
\hline Feed Rate, lph & 400 \\
\hline Evaporator duty, lph & 150 \\
\hline Concentrate Flow Rate, lph & 250 \\
\hline Boiling point of solution, $\mathrm{K}$ & 378 \\
\hline Frictional pressure drop, $\mathrm{N} / \mathrm{m}^{2}$ & 2023 \\
\hline Static pressure drop, $\mathrm{N} / \mathrm{m}^{2}$ & 7206 \\
\hline Total pressure drop, $\mathrm{N} / \mathrm{m}^{2}$ & 11253 \\
\hline Driving force, $\mathrm{N} / \mathrm{m}^{2}$ & 24175 \\
\hline Heat transfer coefficient, $\mathrm{Uc} \quad \mathrm{W} / \mathrm{m}^{2} \mathrm{~K}$ & 1891 \\
\hline Heat transfer coefficient, Ud W/m² $\mathrm{K}$ & 840 \\
\hline Dirt factor, Rd $\mathrm{m}^{2} \mathrm{~K} / \mathrm{W}$ & 0.004 \\
\hline Heat transfer area provided, $\mathrm{m}^{2}$ & 7.181 \\
\hline Heat flux, W/m² & 17839 \\
\hline Shell diameter, $\mathrm{mm}$ & 303 \\
\hline Shell thickness, mm & 6 \\
\hline Tube sheet diameter, $\mathrm{mm}$ & 288 \\
\hline Tube sheet thickness, mm & 38 \\
\hline Number of tubes & 29 \\
\hline Pipe diameter (NB), Sch 40, mm & 25 \\
\hline
\end{tabular}


RASĀYAN J. Chem.

Vol. 11 | No. 1 | 307 - 311 | January - March | 2018

\begin{tabular}{l|l}
\hline Tie rod Diameter, $\mathrm{mm}$ & 9.5 \\
\hline Number of tie rods & 4 \\
\hline Vapour chamber dia, $\mathrm{mm}$ & 700 \\
\hline Mass Flux in vapour chamber, $\mathrm{Kg} / \mathrm{hr}-\mathrm{m}^{2}$ & 400 \\
\hline Evaporator vent pipe (NB), Sch 40, mm & 150 \\
\hline Velocity in vent pipe, $\mathrm{m} / \mathrm{s}$ & 15 \\
\hline Cold leg pipe diameter (NB), Sch 40, mm & 150 \\
\hline Recirculation Ratio & 250 \\
\hline Feed inlet \& outlet nozzle diameter (NB), Sch40, mm & 20 \\
\hline Steam nozzle diameter (NB), Sch 40, mm & 50 \\
\hline Condensate drain nozzle diameter (NB), Sch 40, mm & 15 \\
\hline Baffle Clearance, mm & 3.2 \\
\hline Baffle Diameter (Shell ID- 2x Baffle Clearance) & 296.6 \\
\hline No of Baffles & 8 \\
\hline Vapour Outlet Dia, mm & 80 \\
\hline &
\end{tabular}

\section{CONCLUSION}

Volume reduction method is good practice that is done to reduce the toxic liquid waste which is very tough to handle. Thus this study has revealed that evaporation process can result in volume reduction of nuclear waste and if it is performed by thermosyphon evaporator the result would be better. Thus a suitable evaporator column was designed to perform volume reduction.

\section{REFERENCES}

1. P. Havard, A. Lemmens, K. Mannaerts, Reduction of the Radioactive Waste Volume from Belgian NPP: Reality, Costs and Goals, IAEA-SM-357/4, pp(1-10)1998.

2. Nuclear Fuel Cycle, BARC Highlights, Vol. 1, Mumbai, BARC, 2007.

3. Yuichi Tanimoto, Norikazu Kinoshita, Koji Oishi, Kazuyuki Torii, Kazuo Murakami, Takashi Nakamura,Shun Sekimoto, Koichi Takamiya and Hajimu Yamana in ASME Proceedings of Fuel Cycle, Radioactive Waste Management and Decommissioning, pp321-326 (2012).

4. R. O. Abdel Rahman, A. M. El Kamash, H. F. Ali and Yung-Tse Hung, Overview on Recent Trends and Developments in Radioactive Liquid Waste Treatment Part 1: Sorption/Ion Exchange Technique, International Journal of Environmental Engineering Science, 2, 1(2011)

5. William L. Lennemann, Radioactive Waste Management, IAEA Bulletin.18, 40-47.

6. R. K. Sinnott, Coulson and Richardson, Vol.6, Edn.4 ${ }^{\text {th }}$, Chemical Engineering Design, p.434437(2005)

[RJC-1964/2017] 